\title{
A GEOGRAFIA DESCONHECIDA DE GEORGES BERTRAND: CONTRIBUIÇÕES À DISCUSSÃO E APLICAÇÃO DO "GEOSSISTEMA COMPLEXO” NO BRASIL $^{1}$
}

\section{LA GEOGRAFÍA DESCONOCIDA DE GEORGES BERTRAND: CONTRIBUICIONES A LA DISCUSIÓN Y APLICACIÓN DEL “GEOSISTEMA COMPLEJO” EM BRASIL}

\section{Carlos Eduardo das Neves ${ }^{2}$}

\section{RESUMO}

Os legados teórico-metodológicos sobre geossistema utilizados por pesquisadores brasileiros tem se resumido, de uma forma geral, a três artigos publicados na década de 1970 (BERTRAND, 1971; SOCHAVA, 1977, 1978), especialmente o artigo do geógrafo francês Georges Bertrand, intitulado "Paisagem e Geografia Física Global: esboço metodológico", traduzido e publicado em 1971, o qual desde então apresentou-se enquanto bibliografia básica em muitos programas de pósgraduação no país. A proposta mudou expressivamente a forma de uma geração de geógrafos entenderem a noção de paisagem, bem como as conexões existentes entre a sociedade e a natureza. Entretanto, o resumido conhecimento do legado de Bertrand tem prejudicado o entendimento de sua evolução conceitual, dificultando a utilização teórico-metodológica do geossistema junto aos estudos ambientais na geografia. Nesse cenário, objetiva-se entender a evolução epistemológica do autor, que encontra-se dividida em quatro momentos históricos, que abarcam o período de 1959 a 2014, a fim de reconhecer sua evolução conceitual e encontrar subsídios ao desenvolvimento de uma outra perspectiva de geossistema, pensada para a

\footnotetext{
${ }^{1}$ Pesquisa em desenvolvimento, que conta com o financiamento da Fundação de Amparo à Pesquisa do Estado de São Paulo (FAPESP). Processo no 2015/06558-9. Orientador: Messias Modesto dos Passos (FCT/UNESP).

${ }^{2}$ Doutorando em Geografia - Bolsista FAPESP - FCT/UNESP eduneves_uel@hotmail.com
}

Número Especial da Revista Estudos Geográficos - XIII Seminário da Pós-Graduação em Geografia, Rio Claro, 15(0): 139-166, jan./jun. 2017 (ISSN 1678-698X)

http://www.periodicos.rc.biblioteca.unesp.br/index.php/estgeo 
A geografia desconhecida de Georges Bertrand...

realidade brasileira e aplicada junto ao planejamento ambiental de interface, enfim, uma perspectiva do "geossistema complexo" criado a partir de uma "epistemologia de campo".

Palavras-chave: Geossistema. Sociedade - Natureza. Georges Bertrand. Brasil. França.

\section{RESUMEN}

Los legados teórico-metodológicos sobre geosistema utilizados por investigadores brasileros han sido resumidos, de forma general, en tres artículos publicados en la década de 1970 (BERTRAND, 1971; SOCHAVA, 1977, 1978), especilamente el artículo del francés Georges Bertrand, con el título "Paisaje y Geografía Física Global: bosquejo metodológico", traducido y publicado en 1971, el cual se presentó desde entonces como un referencia bibliográfica básica en muchos programas de posgrados en el país. La propuesta contenida en el articulo cambió sustancialmente la forma en que toda una generación de geógrafos entendían la noción de paisaje, así como las conexiones existentes entre la sociedad y la naturaleza. No obstante, el poco conocimiento del legado de Bertrand limitó el entendimiento de su evolución conceptual, dificultando la utilización teórica-metodológica del geosistema junto a los estudios ambientales en la geografía. En este contexto, se objetiva entender la evolución epistemológica del autor, que se encuentra dividida en cuatro momentos históricos que abarcan el periodo de 1959 hasta 2014, con el fin de reconocer su evolución coneptual y encontrar insumos para el desarrollo de otra perspectiva de geosistema, pensada para la realidad brasilera y aplicada junto a la planificación ambiental de interface, en fin, una perspectiva del "geosistema complejo" creado a partir de una "epistemología de terreno".

Palabras clave: Geosistema. Sociedad - Naturaleza. Georges Bertrand. Brasil Francia.

\section{INTRODUÇÃO}

“(...) um mundo confuso, de geografias confusas” (MONTEIRO, 1988, p. 128).

Como aparecem os modelos científicos de análises integradas do ambiente e da paisagem na França e no Brasil? Quais são as vantagens da teoria do geossistema nos estudos sobre a relação sociedade - natureza na geografia? É importante ter em conta as condições históricas, culturais, políticas e sociais em que apareceram os pressupostos geossistêmicos? Qual a relação entre as pesquisas geossistêmicas brasileiras e as francesas? É necessário entender a ressignificação de conceitos

Número Especial da Revista Estudos Geográficos - XIII Seminário da Pós-Graduação em Geografia, Rio Claro, 15(0): 139-166, jan./jun. 2017 (ISSN 1678-698X)

http://www.periodicos.rc.biblioteca.unesp.br/index.php/estgeo 
A geografia desconhecida de Georges Bertrand...

transportados de realidades distintas? Essas perguntas são trabalhadas de modo interconectado no artigo. Entretanto, não se pretende esgotar tais indagações. Assume-se uma pesquisa em curso.

Nesse âmbito, visando suprir essa carência de informações, objetiva-se realizar uma periodização dos estudos de Georges Bertrand, destacando rupturas em sua obra, fomentando o desenvolvimento conceitual do "geossistema complexo" enquanto uma proposta brasileira ao tema. Esse reconhecimento pode subsidiar 0 desenvolvimento de outra perspectiva de geossistema, pensada para a realidade brasileira e aplicada junto ao planejamento ambiental de interface, que pode ser consolidada pela "epistemologia de campo" realizada por Bertrand.

Nesse intento, utiliza-se como ponto de partida o método de pesquisa históricobibliográfico ou documental (GIL, 1991), abarcando cerca de 70 obras, entre artigos, livros e notas de Georges Bertrand, junto a bancos de dados internacionais. Os artigos do autor são relacionados ao final da pesquisa com as principais contribuições sobre o tema, desenvolvida por ex-professores de universidades paulistas e que são frequentemente utilizados no debate geossistêmico brasileiro.

Com base nessas perspectivas, possibilita-se pensar em um conceito voltado às análises local e local/regional, distinto do que vem se aplicando segundo os pressupostos de Bertrand (1968) e Sochava $(1977,1978)$, especialmente com base em uma epistemologia pensada no campo (BERTRAND, 2010), a partir da práxis geográfica, onde o método é o vetor de sua criação (NUNES, 2015). Assim, desenvolve-se um esboço tipológico de uso do geossistema(s) e do ambiente entendido de modo dialético-sistêmico junto ao planejamento ambiental de interface.

Esse intento divide-se em cinco partes complementares: teórico-metodológica; operacional diagnóstica; prognóstica; e de intervenção (SILVA, 2012). Elas são partes inter-relacionadas no processo de uso do "geossistema complexo" junto ao planejamento ambiental de interface. Seus níveis taxonômicos se dão por meio de seis unidades, que são vistas enquanto sistemas de subsistemas, analisados a partir do princípio de poliestrutura do geossistema (PREOBRAZHENSKI, 1983). Nessa abordagem, a questão de elementos responsáveis pela estruturação do sistema se torna oscilante.

Desse modo, a abordagem compreendida perpassa aproximadamente 60 anos de uma carreira acadêmica combativa de um geógrafo francês que soube assumir o papel de intelectual em uma época de revolução científica e crise ambiental. Essa história, quando deslocada para o Brasil, muito tem a ver com a comemoração dos 40 anos da Pós-Graduação em Geografia da UNESP de Rio Claro. Isso porque, entre as universidades paulistas (USP, UNICAMP e UNESP de Prudente), essa foi a que mais empregou o geossistema em suas dissertações e teses (NEVES, 2015).

Número Especial da Revista Estudos Geográficos - XIII Seminário da Pós-Graduação em Geografia, Rio Claro, 15(0): 139-166, jan./jun. 2017 (ISSN 1678-698X)

http://www.periodicos.rc.biblioteca.unesp.br/index.php/estgeo 


\section{PRESSUPOSTOS, HIPÓTESES, CRÍTICAS E A NECESSÁRIA RESSIGNIFICAÇÃOO DO GEOSSISTEMA NO BRASIL}

A análise proposta almeja que o conceito de geossistema seja utilizado junto ao debate integrativo ambiental de modo mais claro e abrangente, ao passo que é exposto, segundo Sochava $(1977,1978)$, Bertrand (1982), Isachenko (1991) e Christofoletti (1999), como o objeto integrador da "geografia física". Sua criação se deu pela imperativa renovação de métodos de análise do ambiente. Foi o ponto de encontro entre a necessidade de uma teoria capaz de dar conta de novos dados surgidos junto às estações de pesquisa soviéticas, com uma metodologia que enxergasse uma longa história das sociedades e da natureza.

Nesse cenário, o geossistema foi/é utilizado de maneira contínua, sobretudo a partir da década de 1970 no Brasil, quando há a tradução do artigo do geógrafo francês Georges Bertrand (Université Toulouse - Le Mirail/France), intitulado originalmente "Paysage et géographie physique globale: esquisse methodologique" (publicado no ano de 1968) e traduzido para o português pela Profa. Dra. Olga Cruz, do Departamento de Geografia da Universidade de São Paulo (USP), em 1971. A versão em português apresentou grande difusão desde então, como bibliografia básica em muitos programas de pós-graduação, por ser uma grande proposta analítica no âmbito da geografia. É, hoje, um dos artigos mais citados na área da "geografia física" no Brasil, com grande acréscimo de seu resgate pela Revista "Ra'e Ga - O Espaço Geográfico em Análise” (UFPR) em 2004.

A proposta mudou expressivamente a forma de uma geração de geógrafos entenderem a noção de paisagem em sua globalidade e escalaridade (temporalespacial), bem como a conexão dinâmica existente entre sociedade-natureza. Todavia, diversos pesquisadores utilizam a proposta de Bertrand, sem de fato entenderem os seus objetivos de recusa aos padrões fragmentários existentes na geografia regional francesa da época.

Entretanto, o conhecimento resumido de grande parte da obra de autor, tem comprometido o entendimento da evolução teórico-metodológica, epistemológica e filosófica do geossistema pela geografia brasileira. Evidenciar tais apontamentos permite que a pesquisa geossistêmica seja estudada de forma mais abrangente em sua prática e em sua epistemologia.

Possibilita-se, com isso, que autores como Sales (2004, p. 125) não mais tenham razão ao denunciar que a "análise ambiental (...) pautada em geossistema, naturaliza a sociedade, por nivelar a ação social aos demais elementos do meio". Essa afirmação é respaldada pelo desconhecimento trazido em diversas pesquisas brasileiras sobre a temática, como é possível observar em Neves (2015).

Número Especial da Revista Estudos Geográficos - XIII Seminário da Pós-Graduação em Geografia, Rio Claro, 15(0): 139-166, jan./jun. 2017 (ISSN 1678-698X)

http://www.periodicos.rc.biblioteca.unesp.br/index.php/estgeo 
A geografia desconhecida de Georges Bertrand...

Pelo fato de uma série de autores não estarem atentos, a utilização da ideia de geossistema tem se mostrado conflitante, pois conceitos e perspectivas analíticas distintas são utilizadas como se fossem unas, além da sua aplicação ocorrer apenas enquanto uma metodologia de classificação taxonômica da paisagem. Esses equívocos podem ter contribuído para o menor crescimento da utilização do mesmo no cenário geográfico brasileiro (MENDONÇA, 1989) e para uma dificuldade de amadurecimento. Por este motivo, essa teoria é considerada inacabada (PASSOS, 2003) ou em construção (NEVES, et al., 2014).

Nesse cenário, expõe-se que perspectivas criadas em realidades particulares devem ser ressignificadas ao serem deslocadas para outros países e outras épocas. Essa ressignificação não se dá somente em relação aos seus aspectos físicos e suas terminologias, mas também devido aos condicionantes ideológicos, políticos, culturais e linguísticos (FROLOVA, 2006).

Abre-se, portanto, a possibilidade de pensar as gêneses, trajetórias e tendências dessa ciência (VITTE, 2008), não apenas em nível analítico operacional, mas sobretudo em nível de interpretação filosófica (MONTEIRO, 1980). Essa análise permite pensar em outra perspectiva geossistêmica, voltada à realidade brasileira com enfoque na análise da sociedade-natureza de forma amalgamada.

\section{SOBRE A RELAÇÃO ENTRE A GEOGRAFIA FRANCESA E A BRASILEIRA: ONDE SE ENCONTRA O GEOSSISTEMA?}

A relação entre a geografia francesa e a brasileira sempre apresentou "aproximações", "distanciamentos", "exclusividades" e "rupturas" (THÉRY, 2016). Os instrumentos dessa relação, primeiramente de influência francesa, são especialmente os papéis exercidos por professores franceses diante da criação dos primeiros cursos de geografia no Brasil na década de 1930. Destacam-se Pierre Deffontaines (base de Jean Brunhes), Pierre Monbeig e Francis Ruellan (base de Vidal de La Blache), que ajudaram a implantar uma cultura geográfica de base francesa no Brasil, resultando no regime de cátedras e nas perspectivas teóricasmetodológicas seguidas (MOREIRA, 2008).

Com o objetivo de entender esses encontros e desencontros entre a produção realizada nesses dois países, Silva (2016) desenvolveu importante obra (FrenchBrazilian Geography: The Influence of French Geography in Brazil), que objetivou estudar a formação de uma geografia nacional criada a partir relações estabelecidas entre os dois países. O autor apresenta como principais conclusões, uma menor assimetria na relação da geografia produzida entre esses dois países, distinta daquela realizada desde a criação dos cursos de geografia no Brasil, onde se via uma longa história de aplicação de teorias provindas da França.

Número Especial da Revista Estudos Geográficos - XIII Seminário da Pós-Graduação em Geografia, Rio Claro, 15(0): 139-166, jan./jun. 2017 (ISSN 1678-698X)

http://www.periodicos.rc.biblioteca.unesp.br/index.php/estgeo 
A geografia desconhecida de Georges Bertrand...

Atualmente, essa relação não é mais de aprendizado da fundamentação teóricometodológica da escola geográfica francesa, especialmente a partir da década de 1970. O Brasil mudou muito e, com ele, as relações entre os geógrafos desses países também mudaram. Houve, assim, certa ruptura com a geografia francesa de moldes mais clássicos (SILVA, 2012).

É nesse período que se insere a obra de Bertrand (1968), também responsável por uma diferenciação das pesquisas desenvolvidas pela chamada geografia física de moldes regionais. Esta obra é pensada em contraponto à geografia regional francesa e à "distrofia" avistada durante os anos de 1960 a respeito dos estudos da paisagem e da superioridade dos estudos geomorfológicos pela geografia francesa, em relação a outros campos disciplinares (BERTRAND, 1982).

Diferentemente do que avistou Silva (2012), se observa essa troca recíproca entre autores brasileiros que fazem suas pesquisas com base teórica no geossistema, 0 que ainda caracteriza um período de aprendizado, desde a década de 1970. Tal perspectiva pode explicar o pouco "espaço de experiência" quando comparado ao "espaço desconhecido" (Figura 2).

Figura 1: Espaço de experiência e horizonte de expectativa e sua relação com a temática.

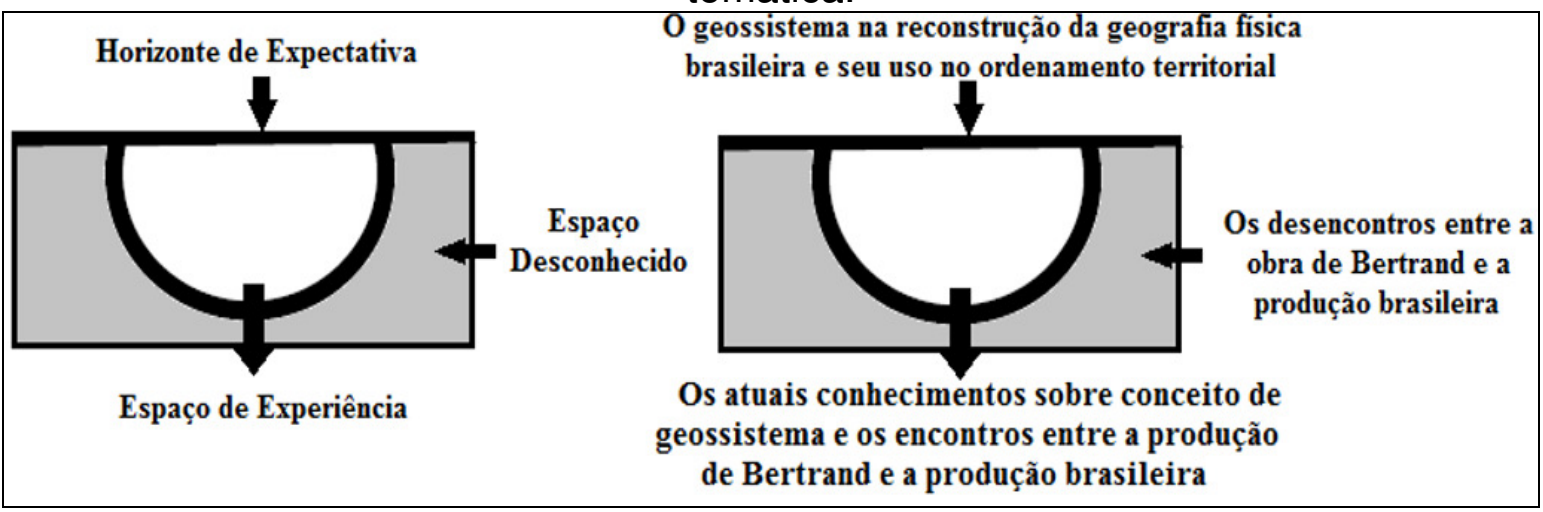

Fonte: Segundo a proposta de Koselleck (2006).

Alargar esse espaço de experiência em relação ao conhecimento da obra de Bertrand é essencial para o uso do geossistema na "reconstrução da geografia física brasileira" e enquanto teoria ao planejamento ambiental de interface.

A esse respeito, Veyret e Vigneau (2002), em seu livro "Géographie Physique. Milieux et environnement dans le système terre", ao objetivarem uma compreensão abrangente do geossistema, através de um conhecimento profundo de cada um dos seus componentes e suas interações, citam a importância de Bertrand (juntamente a Jean Tricart) na renovação da geografia física francesa na década de 1970.

Número Especial da Revista Estudos Geográficos - XIII Seminário da Pós-Graduação em Geografia, Rio Claro, 15(0): 139-166, jan./jun. 2017 (ISSN 1678-698X)

http://www.periodicos.rc.biblioteca.unesp.br/index.php/estgeo 
A geografia desconhecida de Georges Bertrand...

Por extensão, aponta-se a relevância de Bertrand na geografia física brasileira, especialmente devido aos laços teóricos e metodológicos entre as mesmas. Todavia, apesar de ser um dos autores mais utilizados para analisar a interface sociedade-natureza na geografia, ainda se avista um conhecimento irrisório de sua obra, sendo que poucos autores destacam leituras profundas de seu ideário (PASSOS, 2003, 2006; REIS JÚNIOR, 2007a, 2007b, 2013).

Essa reflexão aponta para a diminuição da lacuna geossistêmica existente entre a obra de Bertrand (sobretudo dos russo-soviéticos) e a produção desenvolvida pela geografia produzida no Brasil. Isso permitirá a reconstrução do que é conhecido sobre o autor, bem como uma nova e profícua visão de entrelaçamento entre o passado (o que foi publicado pelo autor e o seu entendimento no Brasil - espaço de experiência) e o futuro (como a geografia brasileira entenderá e utilizará o geossistema - horizonte de expectativa) possibilitando-se, assim, um entrelaçamento entre essas estâncias do tempo (KOSELLECK, 2006).

\section{QUATRO PERÍODOS DA OBRA DE GEORGES BERTRAND: NOTAS PARA UM DEBATE}

As pesquisas desenvolvidas por Bertrand sempre demandaram do geógrafo a não preocupação com os aspectos estritamente naturalistas, mas sim a necessidade ir além, através da visualização dos pontos de embate, dos enclaves entre sociedadenatureza. É o que foi demonstrado no artigo "Le paysage entre la Nature et la Société" (BERTRAND, 1978), talvez a terceira obra mais conhecida do autor no Brasil (atrás de Bertrand (1968) e Bertrand e Bertrand (2002)), mas muito pouco internalizada nas pesquisas que utilizam o autor.

Nesse artigo de 1978, o autor demonstra que essas duas categorias são inseparáveis (sociedade-natureza) ao estudo da paisagem. Seu projeto da paisagem é estendido para as dimensões subjetiva, cultural e simbólica. Nesse viés, Bertrand (1982) propôs edificar o conceito de geossistema como o verdadeiro objeto da geografia física, o seu núcleo central, sem negar a utilidade dos estudos especializados e setoriais. Nesse sentido, a chamada geografia física, através de Bertrand, pôde se compreender, com mais proximidade, a "ação construtiva e destrutiva" da sociedade, disposta no tempo e no espaço (REIS JÚNIOR, 2007a).

Com o conceito de geossistema evidencia-se a possibilidade da geografia enxergar a sociedade através de uma maior interdisciplinaridade com a natureza, se esforçando para transcender as monografias setoriais (BERTRAND; DOLFUSS, 1973). A prerrogativa apresenta-se fundamental à geografia em relação aos demais

Número Especial da Revista Estudos Geográficos - XIII Seminário da Pós-Graduação em Geografia, Rio Claro, 15(0): 139-166, jan./jun. 2017 (ISSN 1678-698X)

http://www.periodicos.rc.biblioteca.unesp.br/index.php/estgeo 
A geografia desconhecida de Georges Bertrand...

subcampos das ciências sociais, dado seu poder em analisar a relação sociedadenatureza na sua interface (BERTRAND, 1978a).

Entretanto, cabe citar que houve certa aversão da geografia francesa às abordagens "globais" de Bertrand (1968), especialmente nas décadas de 1960-1970, o que barrou o desenvolvimento de muitas de suas ideias, com o argumento de que 0 método proposto pelo autor era muito complicado e não suficientemente geográfico (BERTRAND; BERTRAND, 2002).

Enquanto crítica a esta colocação, Bertrand (1982) destacou que a geografia física francesa apresentava-se como um agregado de divergências e uma síntese que desconhecia o sistema. Portanto, esqueceu-se na França e também "no Brasil (?)" que o componente e o sistema só se definem através de suas relações, através de um olhar comum para ambos e para suas complexidades, enfim para o "todo", o seu "conjunto" (BERTRAND, 1986).

Entretanto, havia necessidade de retomar a paisagem de um ponto de vista científico. Sobretudo, devido ao fato da sua definição depender da natureza das pesquisas realizadas, uma vez que se a mesma é uma realidade de essência histórica (social), os naturalistas não são suficientes para esgotar o seu significado e dinâmica. A esse respeito, Bertrand (1984) enfatiza que a paisagem está enraizada no coração da natureza e do social, no núcleo das relações sociais sendo, antes de tudo, um estudo necessário, mas também paradoxal.

Neste panorama, este artigo aponta quatro grandes períodos da caminhada epistemológica e também filosófica do geógrafo francês:

- A paisagem pela via da natureza (1955-1967) permite debruçar-se nas raízes da geografia física e regional francesa, que enfatizou a necessidade de uma reformulação teórica e, acima de tudo, uma ruptura epistemológica que se inicia com a própria inserção do autor no nível superior. Nesse âmbito, aponta-se uma procura ou um resgate da perspectiva da paisagem e sua aplicação junto à geografia francesa. Essa prerrogativa apresentou ao autor a necessidade de rever sua própria concepção filosófica de geografia. Para isso, dever-se-ia reencontrar um elo entre a geografia física e a humana, através de uma dialética maior entre sociedade-natureza. Assim, enquanto categoria base, a paisagem poderia apresentar novamente a importância desejada. Para isso, houve a necessidade de um avanço epistemológico de uma fecunda aproximação entre disciplinas geográficas e talvez entre as ciências. Esse período aponta a necessidade de uma teoria que pudesse dar conta da globalidade e diversidade geográficas e, quem sabe, de uma nova epistemologia, baseada em observações e levantamentos realizados em campo, mas também em um novo paradigma para o estudo da paisagem e da própria geografia.

- A paisagem entre a natureza e a sociedade (1968-1978), inicia-se em 1968 com o conceito de geossistema que se referia a uma taxonomia têmporo-

Número Especial da Revista Estudos Geográficos - XIII Seminário da Pós-Graduação em Geografia, Rio Claro, 15(0): 139-166, jan./jun. 2017 (ISSN 1678-698X)

http://www.periodicos.rc.biblioteca.unesp.br/index.php/estgeo 
A geografia desconhecida de Georges Bertrand...

espacial da paisagem global, com destaque ainda dos conceitos de geofácies e geótopos e a importância da teoria da biostasia e resistasia de Erhart (1956) na análise da dinâmica das unidades de paisagem. Esse período se encerra com uma reavaliação de sua teoria através do contato com as escolas de geografia alemã e russa. $O$ russo Beroutchachvili, com seu grande conhecimento advindo das pesquisas junto à estação experimental de Martkopi (Geórgia), apresenta a Bertrand a importância dos estados de sucessão para o desenvolvimento dos estudos geossistêmicos. Em contrapartida, 0 francês também lhe evidenciou a necessidade de olhar a antropização e socialização dos meios naturais (BERTRAND, 2010).

- A paisagem pela via da sociedade (1979-2007) permitiu o reconhecimento e a crítica à natureza "desnaturada" e das relações da paisagem com o território e com a cultura, possibilitando a criação, em 1991, do sistema tripolar GTP (Geossistema (fonte), Território (recurso) e Paisagem (identidade)) (BERTRAND, 1991; BERTRAND; BERTRAND, 2002). Este criado de modo teleológico e de forma diagonal para o estudo do "meio ambiente do território". O GTP se insere no auge da interdisciplinaridade ambiental, na criação do conceito de sustentabilidade e na emergência de uma problemática socioespacial. Nesse cenário, apenas os conceitos de ecossistema e geossistema não se mostravam suficientes ao entendimento da complexidade e diversidade e complexidade do meio ambiente, havendo a necessidade de repensar a ruptura entre natureza e cultura. Ressalta-se também o avanço, após os anos 2000, no plano epistemológico e metodológico, que se dá devido às inquietações desenvolvidas junto a experiências de viagens de campo a Andalucia (Espanha), Pantanal (Brasil) e Landas (França), o que representa a importância de uma epistemologia criada em distintas realidades e em campo. De acordo com esta lógica, o próprio Bertrand, em 2002, realiza uma reavaliação da sua própria investigação cientifica, com a publicação da obra "Une géographietraversière. L'environnement entre teritoiresertemporalités", permitindo uma ampla avaliação da sua trajetória geográfica e a rejeição de uma censura existente entre a geografia física e humana.

- A partir de 2007 há um retorno da centralidade da dimensão paisagística para o estudo do meio ambiente através do protocolo didático SPT (Sistema Paisagem Território). Nesse protocolo a paisagem deve ser retomada pela base, partindo de um novo paradigma, bem como apresenta uma resposta a investigações vagas e ambíguas que paralisam as pesquisas sobre a categoria paisagem. O protocolo parte de uma vertente epistemológicainterdisciplinar, bem como de um viés metodológico, chegando-se no polo didático, não só interdisciplinar e entre profissões (BERTRAND, 2008), o que de certa forma agrega a territoriaização da paisagem identitária do GTP.

Número Especial da Revista Estudos Geográficos - XIII Seminário da Pós-Graduação em Geografia, Rio Claro, 15(0): 139-166, jan./jun. 2017 (ISSN 1678-698X)

http://www.periodicos.rc.biblioteca.unesp.br/index.php/estgeo 
A geografia desconhecida de Georges Bertrand...

Nesses momentos demonstrados brevemente, a análise do conjunto, global e integral do ambiente mantém-se fortalecida na perspectiva bertraniana, sempre influenciada por sua reflexão de campo, que está a serviço da pesquisa debruçada sobre o mundo real (BERTRAND, 2010), à qual não demanda inventar conceitos, mas redescobri-los em novas realidades e temporalidades (Figura 4).

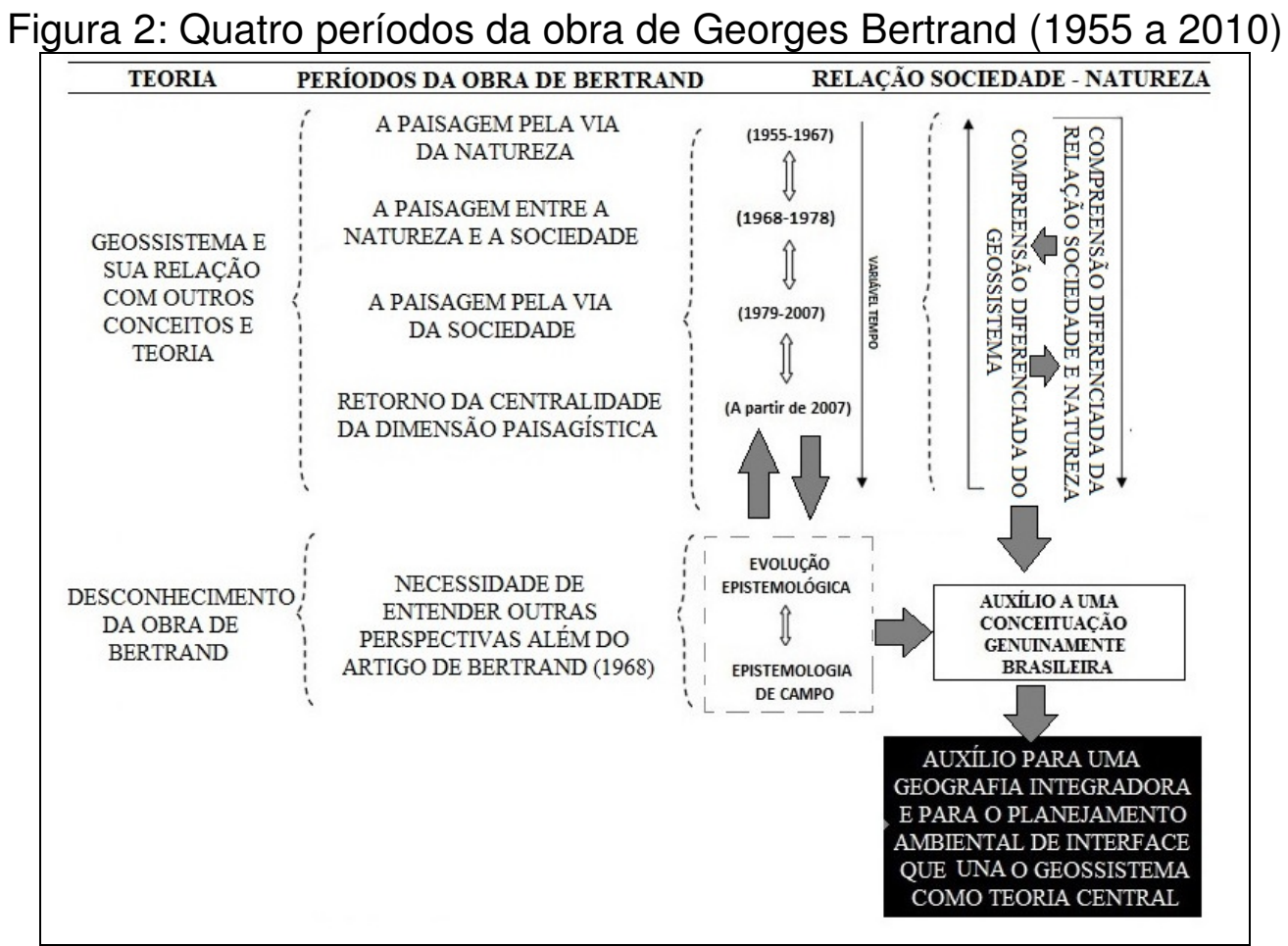

Fonte: Elaboração do autor, 2016.

A partir da análise de seus períodos (Figura 4 e 5) observa-se que em seu caminhar epistemológico, Bertrand deixa de lado a relação igualitária do potencial ecológico, da exploração biológica e da ação antrópica e oferece outro protótipo de análise para o estudo do ambiente do território, o modelo GTP (Geossistema - Território Paisagem) (BERTRAND, 1991), que diminui a importância da "ação antrópica" na concepção de geossistema, exposto enquanto conceito naturalista.

Número Especial da Revista Estudos Geográficos - XIII Seminário da Pós-Graduação em Geografia, Rio Claro, 15(0): 139-166, jan./jun. 2017 (ISSN 1678-698X)

http://www.periodicos.rc.biblioteca.unesp.br/index.php/estgeo 


\section{Figura 3: Síntese das fases de Georges Bertrand e suas respectivas obras}

\begin{tabular}{|c|c|c|}
\hline 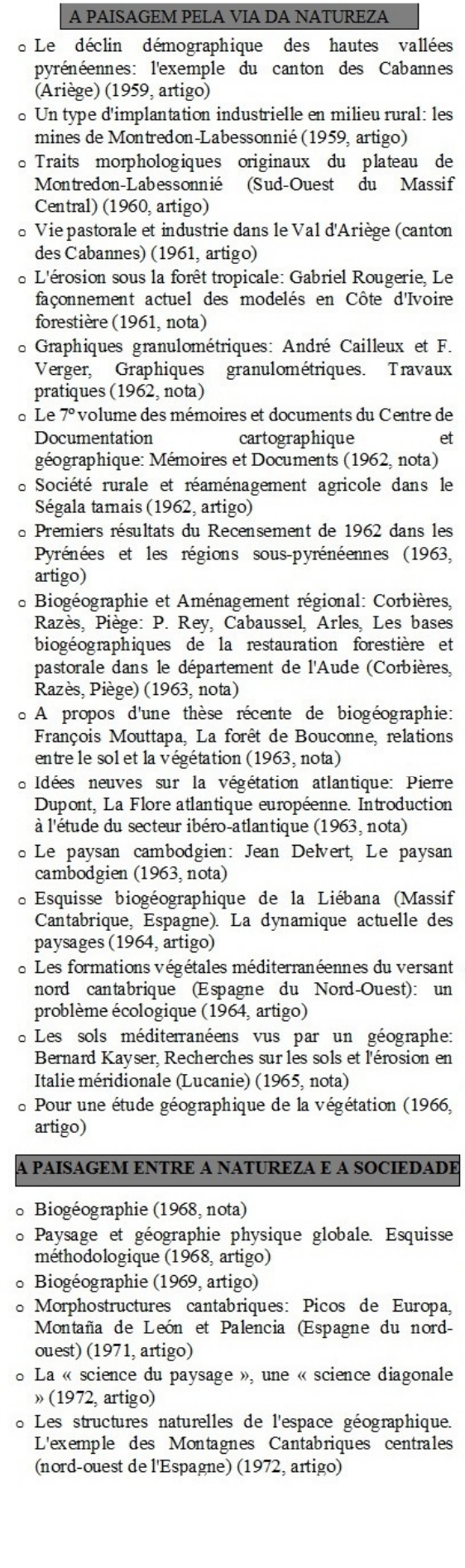 & 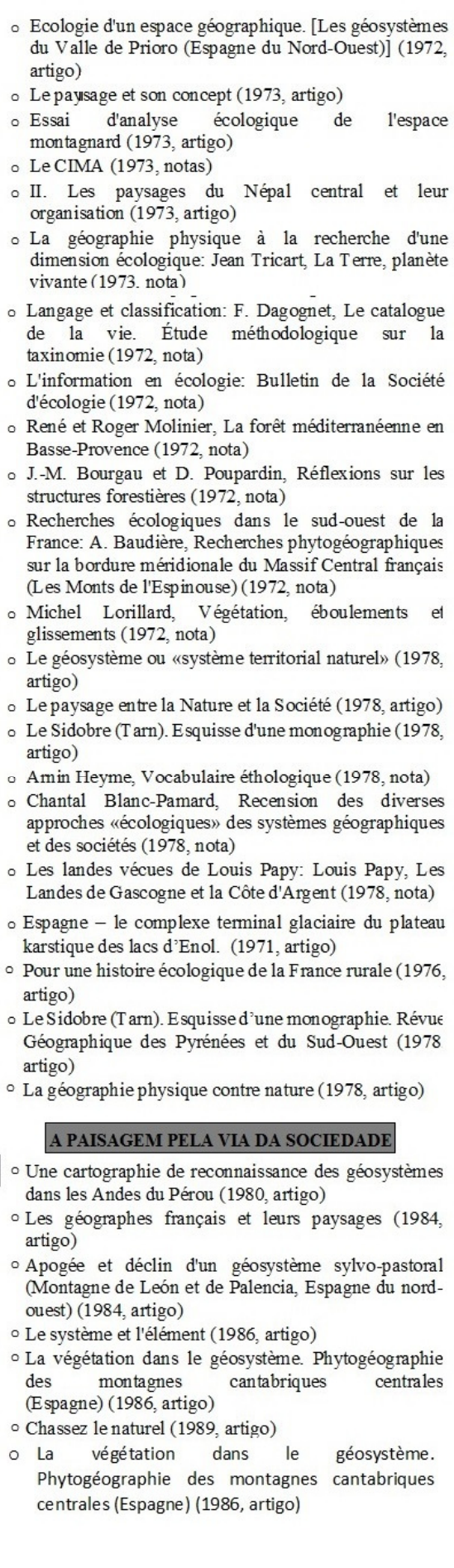 & 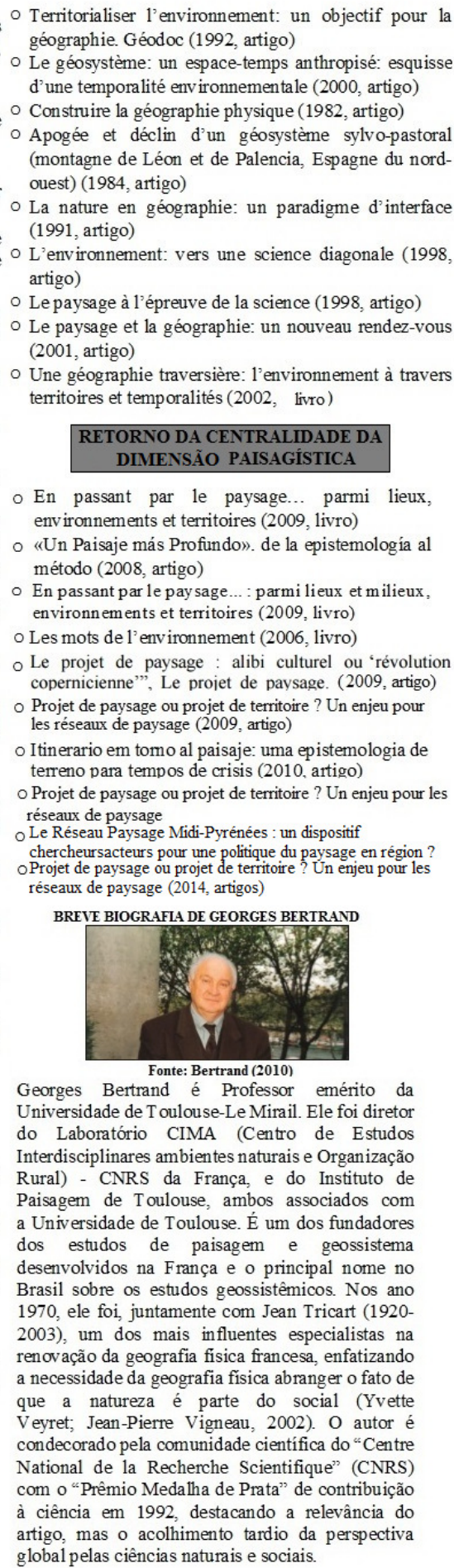 \\
\hline
\end{tabular}

Fonte: Elaborado pelo autor, 2016.

Número Especial da Revista Estudos Geográficos - XIII Seminário da Pós-Graduação em Geografia, Rio Claro, 15(0): 139-166, jan./jun. 2017 (ISSN 1678-698X)

http://www.periodicos.rc.biblioteca.unesp.br/index.php/estgeo 
A geografia desconhecida de Georges Bertrand...

O reconhecimento desses períodos contribui com o que o próprio autor explana acerca da necessidade de uma epistemologia ao alcance das investigações pretendidas (BERTRAND; BERTRAND, 2002, 2014), onde o complexo "objetosujeito" apoia o desenvolvimento de uma epistemologia de campo que objetiva pôr em prova conceitos e métodos, mas que também permite expor o conceito junto à intencionalidade da produção do espaço e das contraditoriedades da produção da natureza - da sua transfiguração.

Recupera-se, ainda, o debate de Beroutchachvili e Bertrand (1978), possibilitando uma uniformização conceitual com os soviéticos, especialmente Sochava (1978). Os autores enfatizam que o estudo do geossistema ao da "ciência do geossistema", deve ser composto de uma análise físico-geográfica, geoquímica e etnológica (variável apresentada especialmente por Bertrand).

Tal prática permite que conceitos "híbridos", tal qual o geossistema, permaneçam úteis ao estudo geográfico da interface sociedade - natureza, especialmente quando é ressignificado, a partir de uma epistemologia de campo, em novos tempos e realidades (Figura 5).

Figura 4: Modelo do Geossistema e do GTP Segundo Pressupostos Bertranianos

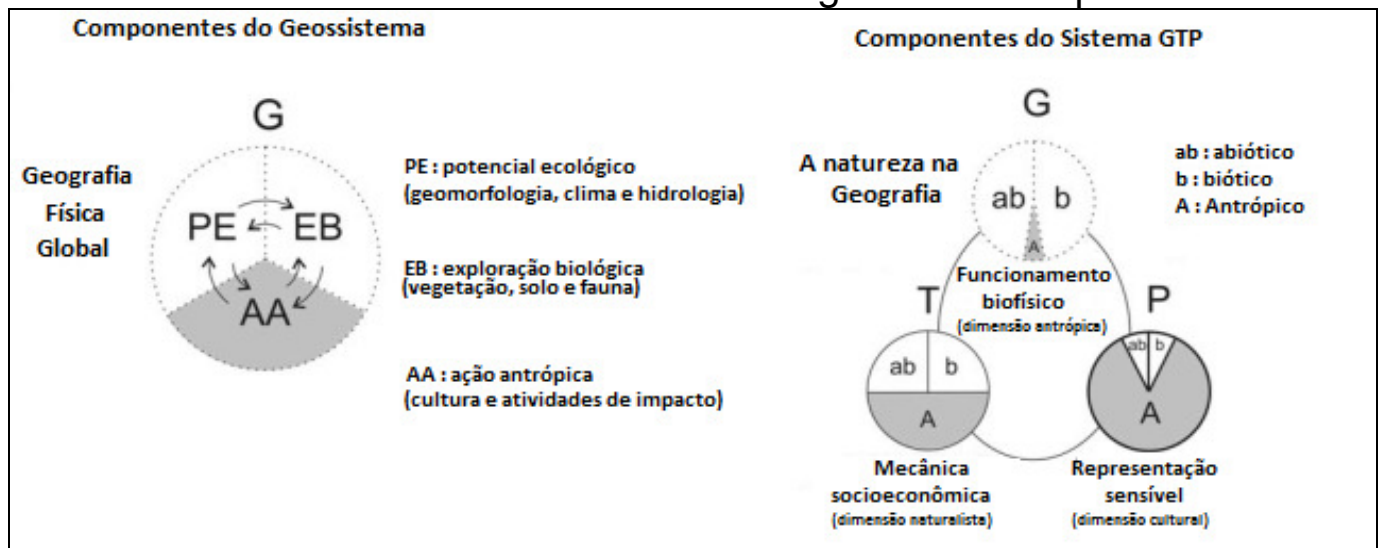

Fonte: Modificado de Reis Júnior (2007a).

Assim, acredita-se que a inserção dos conceitos de território e paisagem no modelo GTP não são redundantes (mas exprimem uma pesquisa de totalidade geográfica, pois representam a trajetória da pesquisa bertraniana de 1959 até 1991). Todavia, suprem a necessidade da dimensão humana e do simbólico participante na formação do ambiente.

Almeja-se, assim, que o GTP seja um fio condutor de conteúdos geográficos, pois ele é de fato um modelo transdisciplinar (realizado como o geossistema de 1968 em campo) que pode ser um (e está sendo?) um modelo operacional, a fim de se Número Especial da Revista Estudos Geográficos - XIII Seminário da Pós-Graduação em Geografia, Rio Claro, 15(0): 139-166, jan./jun. 2017 (ISSN 1678-698X)

http://www.periodicos.rc.biblioteca.unesp.br/index.php/estgeo 
A geografia desconhecida de Georges Bertrand...

tornar uma grande ferramenta didática no estudo da sociedade - natureza que, $\mathrm{n}$ entanto, tem evoluído pouco em sua aplicação (BERTRAND, 2010).

Observa-se, de uma forma geral, que não há como dissociar sociedade - natureza no percurso epistemológico do geógrafo francês. Portanto, a contribuição do mesmo ao estudo da temática no Brasil, deve ir além de sua perspectiva de 1968. Este trabalho é uma possibilidade de análise, uma janela em perspectiva e uma iniciativa, como já demonstrado por Reis Júnior (2007a), ao reconhecimento da obra de um dos mais reconhecidos geógrafos ainda vivos.

Deve-se entender hoje um Bertrand entre os caminhos, interstícios e transversalidades da sociedade - natureza, bem como em sua evolução epistemológica e em seu caráter temporal diferenciado daquele dos início da década de 1960. Ao passo que sua obra se apresenta basilar ao desenvolvimento de uma proposta brasileira.

Essa análise permite gerar produtos complexos, muito além da unidade da paisagem e de uma área natural de elementos interconectados com ou sem a influenciada sociedade. Pode criar um conceito-ferramenta que seja de apoio ao estudo do complexo ambiental atual, o qual é denominado "o geossistema complexo".

Assim, a pesquisa assume, segundo pressupostos defendidos por Beroutchachvili e Bertrand (1978), que o geossistema é tanto um conceito simplificador quanto integrador que faltou, e ainda falta, à geografia física francesa, e também à brasileira, onde a relação entre ambas se faz de extrema importância. Assim, o geossistema complexo insere-se em um discurso amplo que se coloca entre a natureza - sociedade.

\section{POR UMA GEOGRAFIA FÍSICA DE GEOSSISTEMAS COMPLEXOS: NOTAS PARA UM CONCEITO BRASILEIRO}

A aludida proposta baseia-se na Teoria Geral dos Sistemas (BERTALANFFY, 1968), amplamente empregada nas ciências naturais, mas que segundo Gregory (1992, p. 238) se evidencia perigosa quando adotada acriticamente, presumindo "que seja suficiente apenas identificar as estruturas do sistema e delinear as inúmeras variáveis".

Por essa prática ser contraditória à necessidade do debate de interface, a geografia tem sido duramente criticada (PONTES, 1999; SALES, 2004). Todavia, "há que se atribuir grande mérito às supramencionadas [abordagens sistêmicas] metodologias de perspectiva globalizante na geografia física, pois buscaram interagir sociedade e

Número Especial da Revista Estudos Geográficos - XIII Seminário da Pós-Graduação em Geografia, Rio Claro, 15(0): 139-166, jan./jun. 2017 (ISSN 1678-698X)

http://www.periodicos.rc.biblioteca.unesp.br/index.php/estgeo 
A geografia desconhecida de Georges Bertrand...

natureza numa mesma abordagem, e de alguma maneira o fizeram" (MENDONÇA, 2001, p. 126).

Dessa forma, deve-se entender o geossistema enquanto complexo dinâmico e em constante evolução, criado a partir da relação dialética entre sociedade - natureza em suas distintas escalas. Como explicitado na Figura 6, é necessário partir de conceitos mais naturalistas (imagem I) e de estudos que analisam o potencial de degradação de áreas naturais (imagem II) até abranger uma total transfiguração da natureza - gerando um produto híbrido das duas primeiras cenas.

Figura 5: As Etapas da Formação de Geossistemas Complexos

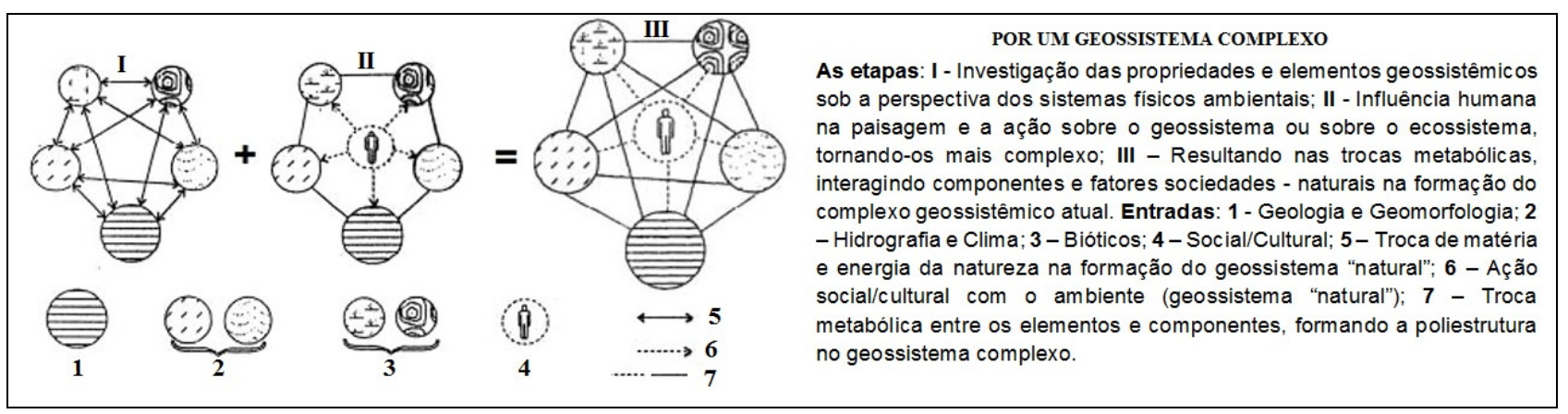

Fonte: Modificado de Melnyk (2008, p. 156).

Esta relação entre conceitos beneficia a análise do geossistema enquanto ferramenta ao estudo do complexo "sociedade - natureza", favorecendo seu uso no planejamento ambiental de interface. Essa forma de entender o geossistema visualiza a globalidade e integridade sociedade - natureza em sua transversalidade disposta no espaço-tempo e também se funda a partir de pressupostos e avanços teóricos e analíticos desenvolvidos por pesquisadores brasileiros que estudaram a temática.

Autores como Ab'Saber (2003); Christofoletti, Monteiro (1982, 1987); Troppmair (1983, 2000) e Passos (2006) contribuíram ao desenvolvimento da temática no Brasil. No entanto, nortearam, de modo geral, suas discussões praticamente nas mesmas concepções teóricas dos demais autores brasileiros, com diferenciação de Passos, que reconheceu grande parte da obra de Bertrand:

1- O geossistema de Bertrand (1971) funda-se na ideia de paisagem enquanto uma porção do espaço que é dinâmica e evolutiva de relação sociedade e natureza. Assim, seu conceito resulta da combinação dinâmica de um determinado potencial ecológico (geomorfologia, clima, hidrologia), de uma exploração biológica (vegetação, solo, fauna) e de atividades "antrópicas".

2- O geossistema de Sochava (1978, p. 292) enfatiza uma "área homogênea de qualquer dimensão onde os componentes da natureza estão em conexões

Número Especial da Revista Estudos Geográficos - XIII Seminário da Pós-Graduação em Geografia, Rio Claro, 15(0): 139-166, jan./jun. 2017 (ISSN 1678-698X)

http://www.periodicos.rc.biblioteca.unesp.br/index.php/estgeo 
A geografia desconhecida de Georges Bertrand...

sistêmicas uns com os outros, interagindo com a esfera cósmica e a sociedade humana".

Apesar dos desencontros, possuíram/possuem vasto conhecimento geográfico que subsidiou outras formas de entender essa relação sociedade - natureza desde o geossistema, se não aqueles de Bertrand e Sochava. Por este motivo, estão entre os autores brasileiros que mais contribuíram ao desenvolvimento de um conceito pensado para a realidade do território brasileiro (Figura 6). São autores que defenderam (e defendem) seu ponto de vista geográfico, assumindo a posição de intelectuais que foram (são) ao aplicar e discutir uma temática que, apesar de complicada, se mostra necessária ao entendimento da geografia integrada aplicada à realidade brasileira.

Figura 6: Importância de autores para uma conceituação brasileira de geossistema complexo.

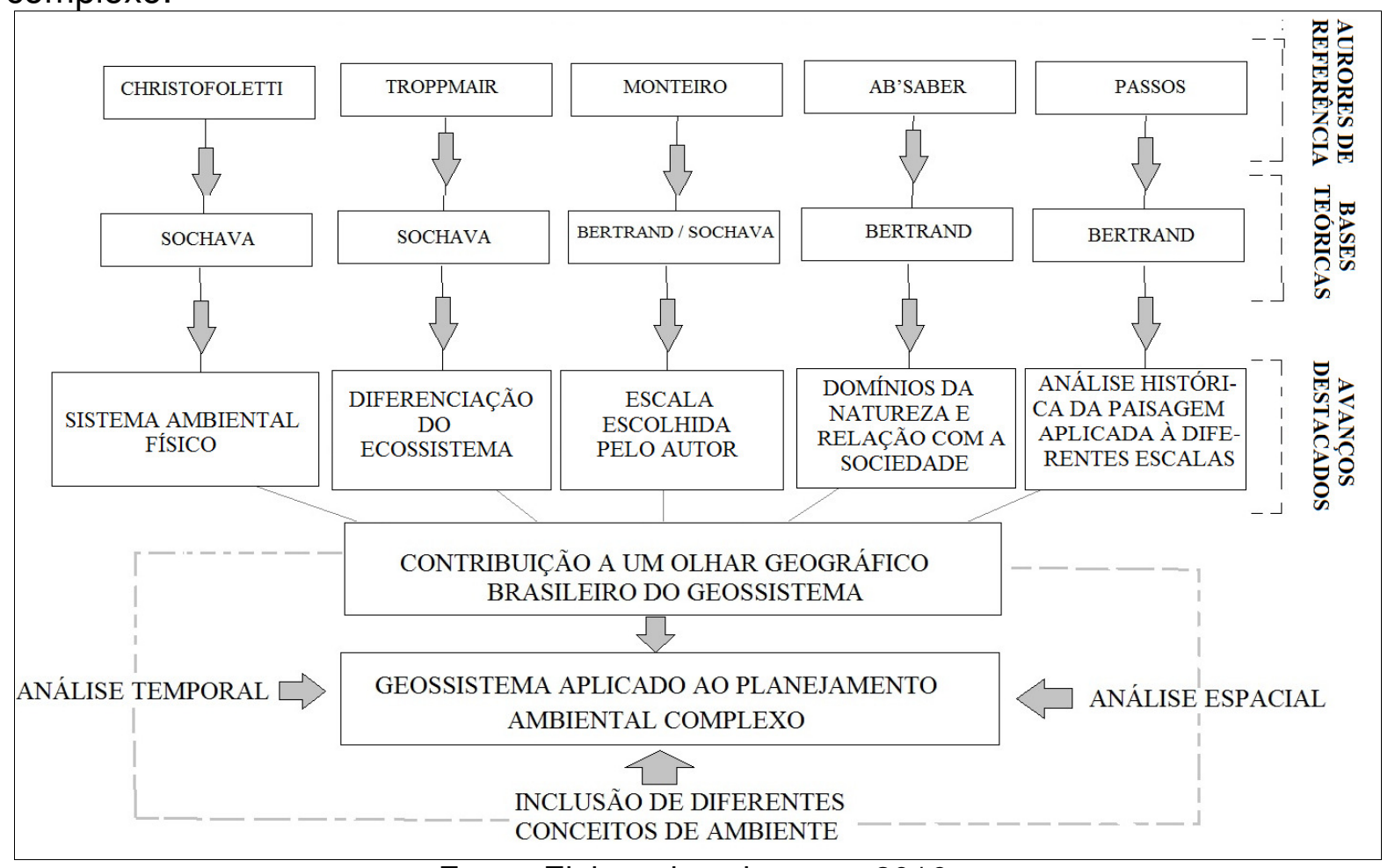

Fonte: Elaborado pelo autor, 2016.

Tal discussão permite a interdependência de perspectivas estruturais, funcionais, dinâmicas e evolutivas provindas da escola Russa, bem como a necessidade da

Número Especial da Revista Estudos Geográficos - XIII Seminário da Pós-Graduação em Geografia, Rio Claro, 15(0): 139-166, jan./jun. 2017 (ISSN 1678-698X)

http://www.periodicos.rc.biblioteca.unesp.br/index.php/estgeo 
A geografia desconhecida de Georges Bertrand...

"socialização da natureza". Isto "(...) nos leva à necessidade de uma reflexão sobre o lugar do estudo de geossistemas no âmbito formal da geografia científica" (CAVALCANTI, 2013, p. 106) e ao seu uso no planejamento, de forma que não subtraia a diversidade cultural em detrimento da biodiversidade. Com tal afirmativa, deixa-se clara a posição do geossistema não ser um conceito apenas para áreas naturais. Se assim o for, certamente não está apto ao entendimento da relação sociedade - natureza.

\section{APLICAÇÃO DO GEOSSISTEMA COMPLEXO: NOTAS A PARTIR DE UM ESBOÇO TIPOLÓGICO DE USO}

Ressalta-se, desta forma, que a utilização da abordagem sistêmico-dialética no planejamento ambiental permite a análise das variáveis através da explicação do todo complexo. Neste âmbito, Santos (2004) enfatiza a importância do planejamento aplicado de modo contínuo, ponto chave ao fomento da conclusão da intrínseca relação entre geossistema e estação experimental (NEVES, 2016).

Nesse viés, por acreditar que a escolha da teoria e método seja um dos principais empecilhos ao desenvolvimento de projetos voltados ao planejamento ambiental dado que grande parte da fundamentação teórico-metodológica utilizada é um tanto fatorial, linear e cartesiana - se esquece da geodiversidade em diferentes taxonomias, dinâmicas e limiares de estabilidade e transformação da natureza sociedade pelo processo intencional de produção do espaço.

Assim, entende-se o uso do geossistema complexo deve partir das dialéticas sociedade - natureza e espaço - tempo, onde sua criação se dá junto à intencionalidade da produção do espaço, mas também incorpora as dinâmicas e processos da natureza, que só podem ser pensados pela relação teoria-prática de uma epistemologia de campo que é pautada em um espaço e tempo especificos.

Para correlacionar os conceitos abordados no esboço tipológico de uso do geossistema complexo, utiliza-se como carro chefe a diferenciação filosófica de ambiente. Isso demonstra que a perspectiva biológica é a mais utilizada, mas não é a mais precisa nas escalas local e local/regional (Quadros 1-a, 1-b, 1-c, 1-d, 1-e e 1f). A fim de discutir esse ponto escalar e relacional, apoia-se em conceitos da "Geoecologia da Paisagem".

Número Especial da Revista Estudos Geográficos - XIII Seminário da Pós-Graduação em Geografia, Rio Claro, 15(0): 139-166, jan./jun. 2017 (ISSN 1678-698X)

http://www.periodicos.rc.biblioteca.unesp.br/index.php/estgeo 
A geografia desconhecida de Georges Bertrand...

Quadro 1-a: Fase Teórico-Metodológica do Planejamento Ambiental de Interface.

\begin{tabular}{|c|c|c|c|c|c|}
\hline & \multicolumn{5}{|c|}{ Fase Teórico-metodológica } \\
\hline $\begin{array}{l}\text { Tipologias } \\
\text { de Análise }\end{array}$ & $\begin{array}{c}\text { Sistema } \\
\text { Ambiental }\end{array}$ & Categorias & $\begin{array}{c}\text { Teoria de Meio } \\
\text { Ambiente Mais } \\
\text { Aplicáveis }\end{array}$ & $\begin{array}{c}\text { Tipos de } \\
\text { Geossistema }\end{array}$ & Geocomponentes \\
\hline I & global & \multirow{2}{*}{$\begin{array}{c}\text { naturais e semi- } \\
\text { naturais }\end{array}$} & \multirow{3}{*}{$\begin{array}{l}\text { meio ambiente } \\
\text { biológico }\end{array}$} & \multirow{3}{*}{$\begin{array}{c}\text { geoecossistema } \\
\text { natural }\end{array}$} & \multirow{3}{*}{$\begin{array}{c}\text { investigação das propriedades e } \\
\text { elementos geossistêmicos sob a } \\
\text { perspectiva dos sistemas físicos } \\
\text { ambientais }\end{array}$} \\
\hline II & zonal/domínio & & & & \\
\hline III & domínio & \multirow[b]{2}{*}{ antroponaturais } & & & \\
\hline IV & regional & & \multirow{3}{*}{$\begin{array}{c}\text { meio ambiente } \\
\text { dialético sistêmico }\end{array}$} & \multirow[t]{2}{*}{$\begin{array}{c}\text { geossistema social } \\
\text { natural }\end{array}$} & $\begin{array}{l}\text { influência humana na paisagem } \\
\text { e a ação sobre o geossistema, } \\
\text { entretanto, observa-se } \\
\text { predomínio das características } \\
\text { naturais } \\
\end{array}$ \\
\hline V & regional/local & & & & \multirow{2}{*}{$\begin{array}{l}\text { interação complexa entre } \\
\text { dinâmica do meio físico com o } \\
\text { meio natural, permitindo o } \\
\text { reconhecimento do complexo } \\
\text { geossistêmico, através da } \\
\text { organização pela produção do } \\
\text { espaço }\end{array}$} \\
\hline VI & local & antrópicas & & $\begin{array}{l}\text { geossistema } \\
\text { complexo }\end{array}$ & \\
\hline
\end{tabular}

Quadro 1-b: Fase Operacional do Planejamento Ambiental de Interface.

\begin{tabular}{|c|c|c|c|c|}
\hline & \multicolumn{4}{|c|}{ Fase Operacional } \\
\hline $\begin{array}{l}\text { Tipologias } \\
\text { de Análise }\end{array}$ & $\begin{array}{l}\text { Escalas de } \\
\text { Planejamento } \\
\text { Ambiental }^{1}\end{array}$ & Unidades de Análise & Escala Cartográfica $^{2}$ & Tipos de Mapeamento \\
\hline 1 & \multirow[t]{2}{*}{ superestratético } & mundo e continente & 1:10.000.000 & mapas muito gerais \\
\hline II & & subcontinente & $1: 5.000 .000$ & mapas gerais \\
\hline III & estratégico & pais & $\begin{array}{c}1: 5.000 .000 \text { até } \\
1: 2.000 .000\end{array}$ & $\begin{array}{c}\text { mapas com pouco } \\
\text { detalhe }\end{array}$ \\
\hline IV & \multirow{2}{*}{$\begin{array}{l}\text { tático - política } \\
\text { regional }\end{array}$} & $\begin{array}{c}\text { região IBGE/ domínio } \\
\text { geomorfológico e biogeográfico, } \\
\text { bacia regional e raia divisória }\end{array}$ & $\begin{array}{c}1: 2.000 .000 \text { até } \\
1: 500.000\end{array}$ & mapas detalhados \\
\hline $\mathrm{V}$ & & $\begin{array}{c}\text { bacia interestadual e parques e } \\
\text { Reservas }\end{array}$ & $\begin{array}{l}1: 500.000 \text { até } \\
1: 100.000\end{array}$ & mapas detalhados \\
\hline VI & operacional & $\begin{array}{l}\text { bacias hidrográficas, bairro, } \\
\text { setores urbanos e rurais }\end{array}$ & $\begin{array}{c}1:: 100.000 \text { até } \\
1: 25.000\end{array}$ & $\begin{array}{l}\text { mapas muito } \\
\text { detalhados }\end{array}$ \\
\hline
\end{tabular}

Número Especial da Revista Estudos Geográficos - XIII Seminário da Pós-Graduação em Geografia, Rio Claro, 15(0): 139-166, jan./jun. 2017 (ISSN 1678-698X)

http://www.periodicos.rc.biblioteca.unesp.br/index.php/estgeo 
A geografia desconhecida de Georges Bertrand...

\begin{tabular}{|c|c|c|c|c|}
\hline \multirow[b]{2}{*}{$\begin{array}{l}\text { Tipologia de } \\
\text { Análise }\end{array}$} & \multicolumn{4}{|c|}{ Fase Diagnóstico } \\
\hline & Tipo de Paisagem ${ }^{3}$ & Impacto sobre a paisagem ${ }^{4}$ & $\begin{array}{c}\text { Escala } \\
\text { Temporal de } \\
\text { Modificacão }^{5}\end{array}$ & $\begin{array}{l}\text { Fase de Equilíbrio } \\
\text { Climáxico }^{6}\end{array}$ \\
\hline 1 & naturais & praticamente nulo & $\begin{array}{l}\text { muito longa/ } \\
\text { centenas de } \\
\text { anos e mais }\end{array}$ & estado natural \\
\hline II & naturais e seminaturais & $\begin{array}{l}\text { quase nulo com focos } \\
\text { limitados de modificação }\end{array}$ & $\begin{array}{c}\text { longa/centenas } \\
\text { de anos }\end{array}$ & presinantropização \\
\hline III & $\begin{array}{c}\text { paisagens pastoris } \\
\text { moderadamente modificadas }\end{array}$ & $\begin{array}{l}\text { desmatamento parcial e uso } \\
\text { extensivo de pastos com } \\
\text { alteração inicial do equilíbrio } \\
\text { geoecológico }\end{array}$ & $\begin{array}{l}\text { longa/média - } \\
50 \text { a } 20 \text { anos }\end{array}$ & preotosinantropização \\
\hline IV & $\begin{array}{l}\text { paisagens agrícolas fortemente } \\
\text { modificadas }\end{array}$ & $\begin{array}{l}\text { desmatamento e aragem } \\
\text { generalizada com substituição } \\
\text { significativa da natureza } \\
\text { (físico) com alteração geral do } \\
\text { equilíbrio ecológico. }\end{array}$ & $\begin{array}{l}\text { média - 20-10 } \\
\text { anos }\end{array}$ & polisinantropização \\
\hline v & $\begin{array}{c}\text { paisagens agrícolas fortemente } \\
\text { transformadas e transformação } \\
\text { antrópica significativa }\end{array}$ & $\begin{array}{c}\text { agricultura generalizada com } \\
\text { significativo avanço da } \\
\text { urbanização. }\end{array}$ & curta - 5-3 anos & $\begin{array}{l}\text { metasinantropização } \\
\text { eusinantropização }\end{array}$ \\
\hline VI & $\begin{array}{l}\text { domínio de paisagens } \\
\text { antrópicas artificiais. área } \\
\text { amplas de recuperação e } \\
\text { sucessão geoecológica. }\end{array}$ & $\begin{array}{l}\text { urbanização e artificialização } \\
\text { generalizada. }\end{array}$ & $\begin{array}{l}\text { muito curta - } \\
\text { até } 2 \text { ano }\end{array}$ & pansinantropização \\
\hline
\end{tabular}

Número Especial da Revista Estudos Geográficos - XIII Seminário da Pós-Graduação em Geografia, Rio Claro, 15(0): 139-166, jan./jun. 2017 (ISSN 1678-698X)

http://www.periodicos.rc.biblioteca.unesp.br/index.php/estgeo 
A geografia desconhecida de Georges Bertrand...

\begin{tabular}{|c|c|c|c|c|c|}
\hline \multirow[b]{2}{*}{$\begin{array}{l}\text { Tipologia de } \\
\text { Análise }\end{array}$} & \multicolumn{5}{|c|}{ Fase Diagnóstico } \\
\hline & Nível Hemeróbico ${ }^{7}$ & $\begin{array}{c}\text { Grau de } \\
\text { Naturalidade }^{8}\end{array}$ & Estabilidade $^{9}$ & $\begin{array}{l}\text { Mudanças na } \\
\text { Estrutura dos } \\
\text { Geossistema }{ }^{10}\end{array}$ & $\begin{array}{c}\text { Mudança na } \\
\text { Composição Floristica e } \\
\text { Faunística }^{11}\end{array}$ \\
\hline 1 & $\begin{array}{l}\text { a-hemerobico } \\
\text { (primogênico) }\end{array}$ & natural & muito alta & \multirow{2}{*}{ não } & 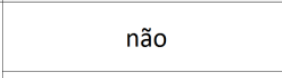 \\
\hline ॥ & $\begin{array}{l}\text { oligo-hemerobico } \\
\text { (transformação leve) }\end{array}$ & $\begin{array}{c}\text { natural e semi- } \\
\text { natural }\end{array}$ & alta & & $\begin{array}{l}\text { maioria das espécies } \\
\text { ocorrem espontâneas }\end{array}$ \\
\hline III & $\begin{array}{l}\text { meso-hemerobico } \\
\text { (tranformação média) }\end{array}$ & $\begin{array}{l}\text { distante do } \\
\text { natural }\end{array}$ & média & pouco visível & $\begin{array}{l}\text { maioria das espécies } \\
\text { ocorrem espontâneas }\end{array}$ \\
\hline IV & $\begin{array}{c}\text { eu-hemeróbico } \\
\text { (extensa transformação }\end{array}$ & $\begin{array}{c}\text { muito distante } \\
\text { do natural }\end{array}$ & baixa & visível & \multirow{2}{*}{$\begin{array}{l}\text { poucas espécies } \\
\text { espontâneas }\end{array}$} \\
\hline V & $\begin{array}{l}\text { poli-hemerobico (maior } \\
\text { grau de transformação) }\end{array}$ & artificial & muito baixa & muito vísivel & \\
\hline VI & $\begin{array}{l}\text { meta-hemerobico } \\
\text { (completamente } \\
\text { tranformação) }\end{array}$ & áreas urbanas & $\begin{array}{l}\text { extremamente } \\
\text { baixa }\end{array}$ & extremamente visível & $\begin{array}{l}\text { apenas espécies } \\
\text { resistentes }\end{array}$ \\
\hline
\end{tabular}

\begin{tabular}{|c|c|c|c|}
\hline & & Fase Prognóstico & \\
\hline $\begin{array}{l}\text { Tipologia de } \\
\text { Análise }\end{array}$ & Estado Ambiental ${ }^{12}$ & $\begin{array}{c}\text { Avaliações Temporais e identificação de alternativas } \\
\text { e contrução de possíveis cenários futuros }{ }^{13}\end{array}$ & Percepção da Ação ${ }^{14}$ \\
\hline 1 & $\begin{array}{l}\text { estável através de } \\
\text { equilíbrio dinâmica }\end{array}$ & \multirow[t]{2}{*}{ avaliação em um longo período de tempo } & \multirow{6}{*}{$\begin{array}{l}\text { construção de cenários, } \\
\text { modelagem e simulação e } \\
\text { análise de agrupamento de } \\
\text { informações }\end{array}$} \\
\hline II & medianamente estável & & \\
\hline III & medianamente estável & avaliação em um médio período de tempo & \\
\hline IV & instável & avaliação em um médio/curto período de tempo & \\
\hline v & crítico & \multirow{2}{*}{ avaliação em um curto período de tempo } & \\
\hline $\mathrm{VI}$ & imsuportável & & \\
\hline
\end{tabular}

Número Especial da Revista Estudos Geográficos - XIII Seminário da Pós-Graduação em Geografia, Rio Claro, 15(0): 139-166, jan./jun. 2017 (ISSN 1678-698X)

http://www.periodicos.rc.biblioteca.unesp.br/index.php/estgeo 
A geografia desconhecida de Georges Bertrand...

Quadro 1-f: Fase Intervenção do Planejamento Ambiental de Interface

\begin{tabular}{|c|c|c|c|c|c|}
\hline \multirow{3}{*}{$\begin{array}{c}\text { Tipologia } \\
\text { de Análise } \\
\text { । }\end{array}$} & \multicolumn{4}{|c|}{ Fase Intervenção } & \multirow{3}{*}{ 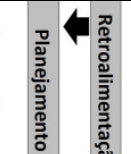 } \\
\hline & \multirow{3}{*}{$\begin{array}{c}\text { Atores da Gestão e Planejamento }^{15} \\
\text { política internacional de } \\
\text { desenvolvimento ambientale } \\
\text { manutenção da bio-geodiversidade }\end{array}$} & \multicolumn{2}{|c|}{ Tomada de Decisão $^{16}$} & Formulação de Diretrizes $^{17}$ & \\
\hline & & \multirow{6}{*}{$\begin{array}{c}\text { seleção de } \\
\text { alternativas: } \\
\text { avaliação técnica } \\
\text { juridica, } \\
\text { administrativa e } \\
\text { financeira das } \\
\text { alternativas; } \\
\text { hierarquização de } \\
\text { alternativas; } \\
\text { definição do modelo } \\
\text { de organização } \\
\text { territorial } \\
\text { geossistêmica } \\
\text { desejada }\end{array}$} & \multirow{6}{*}{$\begin{array}{l}\text { métodos de } \\
\text { ordenação; } \\
\text { matrizes } \\
\text { cruzadas; } \\
\text { métodos } \\
\text { multicriteriais } \\
\text {,as quais } \\
\text { subsidiam as } \\
\text { alternativas } \\
\text { anteriores }\end{array}$} & \multirow{6}{*}{$\begin{array}{c}\text { definição de normas para a } \\
\text { organização territorial } \\
\text { segundo as escalas } \\
\text { analisadas; elaboração de } \\
\text { planos e programas que } \\
\text { apresentem a relação entre } \\
\text { os niveis sociais; propostas } \\
\text { de monitoramento e } \\
\text { controle de acordo com na } \\
\text { potencialidade e } \\
\text { fragilidade dos } \\
\text { geossistemas; elaboração } \\
\text { de mecanismos de gestão }\end{array}$} & \\
\hline "I & & & & & \\
\hline III & política de desenvolvimento regional & & & & D \\
\hline IV & $\begin{array}{l}\text { política de desenvolvimento } \\
\text { interestadual/estadual }\end{array}$ & & & & 4 훔 \\
\hline $\mathrm{v}$ & $\begin{array}{l}\text { política de desenvolvimento } \\
\text { referente as regiões metropolitanas }\end{array}$ & & & & ل胥 \\
\hline $\mathrm{VI}$ & $\begin{array}{l}\text { política de desenvolvimento } \\
\text { municipal/comunitário e manejo de } \\
\text { bacias hidrográficas }\end{array}$ & & & & 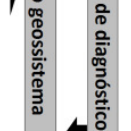 \\
\hline \multicolumn{6}{|c|}{ Fonte: (1) adaptado de Rodriguez et al. (2004) e (2) adaptado de Shishenko (1988). } \\
\hline \multicolumn{6}{|c|}{$\begin{array}{l}\text { Fonte: (3) e (4) adaptado de Isachenko (1991); (5),(10) e (11) adaptado de Noveh e Lieberman (1984) e (6), (7) e } \\
\text { (8) adaptado de Piotrzak (1990) apud Rodriguez et al. (2004) e (9) adaptado de Rodriguez et al. (2004). }\end{array}$} \\
\hline \multicolumn{6}{|c|}{ Fonte: (12) adaptado de Isachenko (1991) e (13) ao (17) Silva (2012) e Santos (2004). } \\
\hline
\end{tabular}

Fonte: Neves, 2015.

Tal metodologia, baseada na relação de tipologia, permite avaliar o estado de hibridização entre sociedade - natureza em distintas escalas espaço-temporais, bem como as oscilações ambientais geradas por esta relação, permitindo a tomada de decisões e formulações de diretrizes compatíveis com o grau homeostásico de cada geossistema. Por isso, o emprego da perspectiva de ambiente dialético-sistêmico se mostra eficaz ao desenvolvimento desse esboço. Com essa perspectiva, é possível entender a complexidade através da busca pelas relações, não aquela de ordem global que afasta sociedade da natureza, mas aqueles que olham a sua dialética e reciprocidade.

Nesse contexto, a partir da leitura do esboço tipológico de uso potencial teóricometodológico do geossistema e do conceito de ambiente dialético-sistêmico, afirmase a diferenciação do geossistema em escala local:

- Nas escalas taxonômicas abrangidas pelas unidades I e II (global e zona/domínio) a perspectiva de meio ambiente, segundo o limiar homeostático e o nível hemeróbico do sistema, pode ainda apresentar uma perspectiva um tanto quanto "biológica", como tem sido realizado corriqueiramente nos estudos ambientais, a qual coloca o homem enquanto um agente externo ao sistema. Isso se explica, pois acredita-se que o homem não muda a forma e o funcionamento do sistema nessas escalas (apesar de causar constantes tensões, não muda a sua essência). Evidenciar essa posição não significa concordar com a superioridade do conceito de ecossistema em detrimento do geossistêmico, uma vez que apesar da

Número Especial da Revista Estudos Geográficos - XIII Seminário da Pós-Graduação em Geografia, Rio Claro, 15(0): 139-166, jan./jun. 2017 (ISSN 1678-698X)

http://www.periodicos.rc.biblioteca.unesp.br/index.php/estgeo 
A geografia desconhecida de Georges Bertrand...

importância da análise vertical, a análise horizontal é essencial para avaliar os estágios de equilíbrio dinâmico e rupturas climáxicas nos geocomplexos nessas escalas.

- Entretanto, nas unidades III e IV e, especialmente, nas taxonomias representadas por $\mathrm{V}$ e $\mathrm{VI}$, a perspectiva de ambiente biológico e geossistema natural não se aplicam mais, uma vez que o nível de modificação na estrutura e funcionamento do sistema tende a aumentar de acordo com o nível de detalhamento (onde o uso da técnica é mais intenso). Nas unidades taxonômicas III e IV o tempo lento, que escoa, e o tempo rápido, que faz, começam a se confundir. No entanto, a diferenciação do que é e o que não é artificial pode ser ainda distinguido. Há processos, tais como o ciclo hidrológico não se apresenta extremamente modificado, pois evidencia a possibilidade do reencontro do estágio de equilíbrio dinâmico caso a tensão seja retirada, mesmo que pelo modo de produção do espaço atual isso se encontre longe de ocorrer.

- Todavia, nas unidades V e VI o "tempo é rápido", bem como os distúrbios e os eventos associados a estas unidades; as mudanças ambientais são observadas e sentidas de maneira abrupta. O conceito de geossistema e a perspectiva de ambiente não podem ser os mesmos das escalas superiores, uma vez que a estrutura e o funcionamento do sistema foram intensamente modificados, podendo-se incluir a esta análise a perspectiva da poliestrutura do sistema (sistema de subsistemas). Nestas escalas, o geossistema tem que ser trabalhado de maneira mais complexa, por isso, a possibilidade de ver a análise sistêmica de forma dialética, onde a relaçãosociedade - natureza não pode ser tratada de forma desconexa, contraditória e excludente. Forma-se, assim, um novo entendimento do geossistema, somente pelo debate amalgamado entre sociedade - natureza. De fato, se as instabilidades do sistema, tais como uma erosão (possui origem natural), tornam-se cada vez mais uma produção social, há uma artificialização dos processos geomorfológicos. Observa-se, assim, que os sistemas mais próximos às escalas locais (geossistema complexo) apresentam também uma maior sensibilidade às tensões, gerando consequências alarmantes na população que sente e vive em os ritmos da natureza. Nessa escala ocorre uma menor tendência de auto regulação que garanta sua existência, aumentando a tendência a oscilações, ou seja, à entropia. Assim, o comportamento do sistema ao impacto deve ser considerado de forma integrada e em distintas escalas. Por isso, a possibilidade do uso da perspectiva trazida pelo esboço delineado.

Aplicar a análise dialético-sistêmica junto ao planejamento e gestão ambiental "permite incorporar a esse processo as seguintes características: objetividade, coerência, análise dialética das contradições e implementação de técnicas e

Número Especial da Revista Estudos Geográficos - XIII Seminário da Pós-Graduação em Geografia, Rio Claro, 15(0): 139-166, jan./jun. 2017 (ISSN 1678-698X)

http://www.periodicos.rc.biblioteca.unesp.br/index.php/estgeo 
A geografia desconhecida de Georges Bertrand...

procedimentos para garantir um processo mais eficaz e eficiente" (RODRIGUEZ; SILVA, 2013, p. 310-311). As mesmas possibilitam comparar estados anteriores ao atual, norteando a situação desejada para o futuro.

Essa discussão pode auxiliar a sociedade no equacionamento dos problemas ambientais atuais e futuros, pois o “(...) planejamento ambiental visa analisar a realidade a partir do desvendar de processos históricos, conectando eventos do passado, condições atuais e possibilidades futuras" (SILVA, 2012, p. 41), intervindo através de políticas de desenvolvimento de longo, médio e curto prazos, em distintas escalas.

Através do esboço tipológico, pode-se apresentar um grande auxílio ao trabalho cotidiano do geógrafo. No entanto, essa intervenção deve partir de um referencial teórico-metodológico que, de fato, compreenda a complexidade da relação sociedade - natureza, atuante no funcionamento, dinâmica e evolução do ambiente. Somente assim, o "geossistema complexo" ou de perspectivas mais tradicionais de geossistema poderá ser útil aos estudos ambientais.

\section{CONSIDERAÇÕES FINAIS}

A contribuição dos estudos de Georges Bertrand se dá pela aproximação aos estudos geossistêmicos da relação dialética sociedade - natureza, o que exprime sua complexidade, analisada de forma conjuntiva, integrada e global. Destaca-se que a discussão brasileira sobre o autor deve transpor a discussão de geossistema enquanto "uma unidade da paisagem", ao passo que o mesmo é uma teoria aplicada a distintas escalas, o que nos aproxima da análise teórica e prática dos geossistemas em distintos níveis taxonômicos. Todavia, esse conceito complexo deve ser aplicado na interface da teoria e da práxis, a partir de uma "epistemologia de campo".

Procedimentos metodológicos como o esboço tipológico apresentado pelos Quadros, podem ser adotados em estudos que relacionem o geossistema a um conceito de caráter complexo, o qual só pode ser teorizado a partir de um conceito dialético-sistêmico de ambiente. Entretanto, pode ser útil ao ordenamento territorial em escalas regionais, relacionando a perspectiva aqui adotada aos domínios de natureza de Ab'Saber (2003).

Nesse viés, é possível que os constantes erros de aplicação e desconhecimento teórico-metodológico do geossistema possam ser minimizados ao serem aplicados aos estudos ambientais sob novas perspectivas. Esse câmbio poderá ocorrer a partir de uma mudança de perspectiva epistemológica dos autores que trabalham especificamente com o estudo das dinâmicas da natureza (sem a sociedade enquanto par dialético).

Número Especial da Revista Estudos Geográficos - XIII Seminário da Pós-Graduação em Geografia, Rio Claro, 15(0): 139-166, jan./jun. 2017 (ISSN 1678-698X)

http://www.periodicos.rc.biblioteca.unesp.br/index.php/estgeo 
A geografia desconhecida de Georges Bertrand...

Finalizamos com diversas perguntas que permitem um processo reflexivo amplo sobre o papel do estudo do geossistema complexo na geografia: 1) Esse viés de geossistema complexo é ainda reducionista, estruturalista, especialmente por ter origem natural ou apresenta a dinâmica necessária para a visualização da natureza amalgamada à sociedade, sendo assim um produto híbrido? 2) Esse conceito complexo é ainda o geossistema naturalista, só que mais "socializado", ou já é outro conceito? 3) Por que o geossistema em escalas local e local/regional pode ser considerado complexo? 4) Por que a "epistemologia de campo" pode ser uma forma palpável de aproximar a teoria da práxis? 5) O geossistema complexo é uma contribuição de importância não somente ao trabalho prático, mas a um olhar epistemológico e filosófico sobre a geografia que se faz? 6) O geossistema complexo permite cumprir um papel de resgate da essência geográfica, por isso é uma forma de ressignificação ou constitui um outro conceito, fora da proposta geossistêmica tradicional de estudo de áreas naturais? 7) Por isso parte de outro princípio epistêmico e ontológico de ver a integração sociedade - natureza?

Todavia, tal debate caminha paralelamente às críticas realizadas ao conceito de geossistema avistado no debate geográfico atual. Ao passo que temos a clareza de que: 1) como todos os modelos de estudo do ambiente, o geossistema complexo simplifica a realidade; 2) o geossistema complexo, como outras teorias, é uma possibilidade de olhar e estudar a geografia e 3) por isso, não explica totalmente os problemas ambientais atuais.

Por fim, deixa-se claro que um olhar por uma janela (neste caso o geossistema) é sempre em perspectiva, por este motivo o caminhar deve ser constante e crítico. Como já disse Talleifer a Bertrand "uma ciência que não evolui é uma ciência morta". Por isso, utilizar perspectivas geossistêmicas pensadas para realidades e tempos particulares não é fecundo.

Número Especial da Revista Estudos Geográficos - XIII Seminário da Pós-Graduação em Geografia, Rio Claro, 15(0): 139-166, jan./jun. 2017 (ISSN 1678-698X)

http://www.periodicos.rc.biblioteca.unesp.br/index.php/estgeo 
A geografia desconhecida de Georges Bertrand...

\section{REFERÊNCIA}

AB'SÁBER, A. N. Os domínios de natureza no Brasil: potencialidades paisagísticas. 3. ed. Ateliê Editorial, 2003.

BEROUTCHACHVILI, N.; BERTRAND, G. Le géosystème ou "système territorial naturel”. Révue Géographique des Pyrénées et du Sud-Ouest, Toulouse, v. 49, n. 2, p. 167-180, avr. 1978.

BERTALANFFY, L. V. General System Theory. George Braziller: New York, 1968.

BERTRAND, C. BERTRAND, G. La nature-artefact: entre anthropisation et artialisation, l'expérience du système GTP (Géosystème-Territoire-Paysage)

L'Information géographique. Armand Colin 3 (Vol. 78), p.128, 2014.

BERTRAND, C.; BERTRAND, G. Une géographie traversière: l'environnement à travers territoires et temporalités. Paris: Éditions Arguments, 2002. 311p.

BERTRAND, G. Le paysage entre la nature et la société. Révue Géographique des Pyrénées et du Sud-Ouest, Toulouse, v. 49, n. 2, p. 239-258, avr. 1978.

BERTRAND, G. Construire la géographie physique. Herodote, Paris, n. 26, p. 90116, août/oct. 1982.

BERTRAND, G. Itinerario en torno al paisaje: uma epistemología de terreno para tiempos de crisis. Ería, v.81, p.5-38, 2010.

BERTRAND, G. La Géographie physique contre nature?. Géodoc, n. 8, 1978b.

BERTRAND, G. La nature en géographie: un paradigme d'interface. Géodoc, n. 34, p. 116, 1991.

BERTRAND, G. Le système et l'élément. Révue Géographique des Pyrénées et du Sud-Ouest, Toulouse, v. 57, n. 3, p. 281-282, juil./sept. 1986.

BERTRAND, G. Les géographes français et leurs paysages, Annales de Géographie, 218-229, 1984.

BERTRAND, G. Paysage et géographie physique globale: esquisse méthodologique. Révue Géographique des Pyrénées et du Sud-Ouest, Toulouse, v. 39, n. 3, p. 249-272, 1968.

BERTRAND, G. Un paisaje más profundo de la epistemología al método.

Cuadernos Geográficos. v. 42, p. 1727, 2008.

Número Especial da Revista Estudos Geográficos - XIII Seminário da Pós-Graduação em Geografia, Rio Claro, 15(0): 139-166, jan./jun. 2017 (ISSN 1678-698X)

http://www.periodicos.rc.biblioteca.unesp.br/index.php/estgeo 
A geografia desconhecida de Georges Bertrand...

BERTRAND, G.; DOLFUSS, O. Essai d'analyse écologique de l'espace montagnard. L’Espace Géographique, Paris, v. 2, n. 3, p. 165-170, 1973.

BERTRAND, G. Paisagem e geografia física global: esboço metodológico. Caderno de Ciências da Terra, n. 13, p. 1-27, 1971.

CAVALCANTI, L. S. Da descrição de áreas à teoria dos geossistemas: uma abordagem epistemológica sobre sínteses naturalistas. 216 f. (Tese de Doutorado em Geografia). Universidade Federal de Pernambuco, 2013.

CHRISTOFOLETTI, A. Modelagem de Sistemas Ambientais. São Paulo. Edgard Blücher,1999.

FROLOVA, M. Desde el concepto de paisaje a la Teoría del geosistema en la Geografía rusa: ¿hacia una aproximación global del medio ambiente? Ería 70: 225235, 2006.

GIL, A. C. Métodos e Técnicas de Pesquisa Social. São Paulo, Atlas, 1991.

GREGORY, K. J. A natureza da geografia física. Rio de Janeiro: Bertrand Brasil, 1992.

ISACHENKO, A. G. A Ciência da paisagem e a regionalização físico-geográfica. Moscou: Editora da Escola Superior, 1991 [em russo]

KOSELLECK, R. Futuro Passado - contribuição à semântica dos tempos históricos. RJ: Contraponto, 2006.

MELNYK, A. Ecological analysis of landscapes. In: ANDREYCHOUK, V. (Ed.) Methodology of Landscape Research. Commission of Cultural Landscape of Polish Geographical Society, Sosnowiec, 2008.

MENDONÇA, F. A. Geografia socioambiental. Terra Livre, São Paulo, n. 16, p. 113$1321^{\circ}$ semestre, 2001.

MONTEIRO, C. A. F. (Coord.) Qualidade ambiental na Bahia: Recôncavo e regiões limítrofes. Salvador: CEI, 1987.

MONTEIRO, C. A. F. A Geografia no Brasil (1934-1977): avaliação e tendências. Universidade de São Paulo. Série Teses e Monografias n. 37. Instituto de Geografia, São Paulo, 1980.

Número Especial da Revista Estudos Geográficos - XIII Seminário da Pós-Graduação em Geografia, Rio Claro, 15(0): 139-166, jan./jun. 2017 (ISSN 1678-698X)

http://www.periodicos.rc.biblioteca.unesp.br/index.php/estgeo 
A geografia desconhecida de Georges Bertrand...

MONTEIRO, C. A. F. The Environmental quality in the Ribeirão Preto Region, SP - an attempt. Commision on Environmental Problems, São Paulo, UGI, 1982.

MONTEIRO, C. A. F. Travessia da crise (tendências atuais na geografia). Revista Brasileira de Geografia, Rio de Janeiro, ano 50, n. especial, t. 2, 1988, p. 127-150.

MOREIRA, R. O pensamento geográfico brasileiro, as matrizes clássicas originárias. São Paulo: Contexto, 2008.

NEVES, C. E. "Geossistema: a História de uma Pesquisa" - Trajetórias e Tendências no Estado de São Paulo. 191 f. Dissertação. (Mestrado em Geografia), Departamento de Geociências da Universidade Estadual de Londrina, Paraná, 2014.

NEVES, C. E Geossistema e Geografia Soviética: os legados teóricometodológicos e a importância dos institutos e estações experimentais de pesquisa. In: $15^{\circ}$ Seminário Nacional da História da Ciência e Tecnologia, 2016, Florianópolis. Anais Eletrônicos do 15온 SNHCT, v. 15, p. 1-18, 2016.

NEVES, C. E.; MACHADO, G.; HIRATA, C. A.; STIPP, N. A. F. A importância dos geossistemas na pesquisa geográfica: uma análise a partir da correlação com o ecossistema. Sociedade \& Natureza. v. 26, n. 2, p. 271-285, 2014.

NUNES, J. O. R. Geografia e a busca pelas articulações. Geographia Meridionalis, v. 01, n. 01, p. 03-29Jun/2015.

PASSOS, M. M. A Raia Divisória: geossistema, paisagem e eco-história. Maringá: Eduem, 2006.

PASSOS, M. M. Biogeografia e Paisagem. Presidente Prudente: UNESP, 2003.

PONTES, B. M. S. A ciência geográfica e o desafio da questão natureza/sociedade. Sociedade \& Natureza, ano 11, n. 21 e 22, jan./dez., 1999, p. 29-44.

PREOBRAZHENSKIY, V. S. Geosystem as an Object of Landscape Study. Geojournal, v. 7, n. 2, p.131-134, 1983.

REIS JÚNIOR, D. F. C. A nova geografia física bertrandiana (é possível tornar humanístico um fisiógrafo?). Revista Geonorte, Edição Especial, v.4, n.4, p.34- 46, 2012.

REIS JÚNIOR, D. F. C. História de um Pensamento Geográfico: Georges Bertrand. Geografia, Rio Claro, v. 32, n. 2, p. 363-390, mai./ago. 2007a.

REIS JÚNIOR, D. F. C.; HUBSCHMAN, J. Pensamento geossistêmico oriental (voz e reverberação). Geografia, Rio Claro, v. 32, p. 555-569, 2007.

Número Especial da Revista Estudos Geográficos - XIII Seminário da Pós-Graduação em Geografia, Rio Claro, 15(0): 139-166, jan./jun. 2017 (ISSN 1678-698X)

http://www.periodicos.rc.biblioteca.unesp.br/index.php/estgeo 
A geografia desconhecida de Georges Bertrand...

REIS JÚNIOR. D. F. C. Conversas sobre o pensamento: Georges Bertrand e a erradia geografia. Geografia, Rio Claro, v. 32, n. 2, p. 500-513, mai./ago. 2007b.

RODRIGUEZ, J. M. M.; SILVA, E. V. A. Planejamento e Gestão Ambiental: subsídios da geoecologia das paisagens e da teoria geossistêmica. Fortaleza: Edições UFC, 2013.

RODRIGUEZ, J. M. M.; SILVA, E. V. A.; CAVALCANTI, A. P. B. Geoecologia das Paisagens: uma visão geossistêmica da análise ambiental. Fortaleza: Editora UFC, 2004.

SALES, V. C. Geografia, sistemas e análise ambiental: abordagem crítica. Geousp, São Paulo, n. 16, p. 125-141, 2004.

SANTOS, R. F. Planejamento Ambiental: teoria e prática. São Paulo: Oficina de Textos, 2004.

SILVA, C. A. Planejamento Ambiental e Turismo, a construção de um modelo teórico-metodológico de análise. In: Geografia e Natureza: experiências e abordagens de pesquisa. UFGD, 2012.

SILVA, J. B. French-Brazilian Geography The Influence of French Geography in Brazil. 1.ed. Berlin: Springer Verlag, 2016. v. 1. 232p.

SOCHAVA, V. B. O Estudo de Geossistemas. Métodos em Questão. São Paulo. n. 16, p. 1-52, 1977.

SOCHAVA, V. B. Por uma teoria de classificação de geossistemas da vida terrestre. São Paulo: Instituto de Geografia, USP, 1978.

THÉRY H. França e a Escola Brasileira de Geografia em inglês, Confins [Online], 27|2016, posto online no dia 20 Julho 2016, consultado o 08 Novembro 2016. URL: $<$ http://confins.revues.org/10990>.

TROPPMAIR, H. Ecossistemas e Geossistemas do Estado de São Paulo. Boletim de Geografia Teorética, Rio Claro, v.13, n. 15, p. 27-36, 1983.

TROPPMAIR, H. Geossistemas e geossistemas paulistas. Rio Claro: UNESP, 2000.

VEYRET, Y.; VIGNEAU, J. P. Géographie physique. Milieux et environnement dans le système terre. Paris, Armand Collin, 2002.

Número Especial da Revista Estudos Geográficos - XIII Seminário da Pós-Graduação em Geografia, Rio Claro, 15(0): 139-166, jan./jun. 2017 (ISSN 1678-698X)

http://www.periodicos.rc.biblioteca.unesp.br/index.php/estgeo 
A geografia desconhecida de Georges Bertrand...

VITTE, A. A Geografia Física no Brasil: Um panorama quantitativo a partir de periódicos nacionais (1928-2006). Revista da ANPEGE, n. 4, p. 47-60, 2008.

Número Especial da Revista Estudos Geográficos - XIII Seminário da Pós-Graduação em Geografia, Rio Claro, 15(0): 139-166, jan./jun. 2017 (ISSN 1678-698X)

http://www.periodicos.rc.biblioteca.unesp.br/index.php/estgeo 